\title{
From Świdnica to Bratislava: The sculpture of Christ the Saviour from the collection of the Slovak National Gallery ${ }^{1}$
}

\author{
Artur Kolbiarz
}

Artur Kolbiarz, PhD
University of Silesia in Katowice
Institute of Art Studies
Poland
e-mail: artur.kolbiarz@us.edu.pl

Mureológia a kultúrne dedičstvo, 2020, 8:3:75-93

DOI: $10.46284 / \mathrm{mkd} .2020 .8 .3 .4$

From Świdnica to Bratislava: The sculpture of Christ the Saviour from the collection of the Slovak National Gallery

Among the works that stand out in the Baroque sculpture collection of the Slovak National Gallery (SNG) is the figure of the Saviour by Georg Leonhard Weber of Świdnica. Surveys conducted in Slovak, Czech and Polish museums, combined with field studies, have made it possible to provide hitherto unexplored artistic context of the work. They have made it possible to trace the formal origins of the Bratislava Saviour as well as its later imitations. The sculpture is carved with virtuosic precision; it develops a concept derived from ancient art and is the finest example of Weber's early oeuvre. Also, it constitutes a link between works made in his workshop over four decades. The present study demonstrates the advantages of an interdisciplinary and international analysis of museum collections. It highlights the significance of the sculpture in question to Central European cultural heritage, expanding the knowledge of museum collections in three different countries.

Keywords: Baroque sculpture in Silesia; Georg Leonhard Weber; gallery and museum collections; cultural heritage; Slovak National Gallery.

The early modern sculpture collection of the Slovak National Gallery in Bratislava has been systematically expanded to include works complementing the varied panorama of Central Europe's cultural heritage, presented at the gallery's exhibitions. One of the exhibits, purchased in 1979, is a sculpture representing Christ the Saviour. ${ }^{2}$ The wooden polychrome figure is signed and dated in an inscription found on its base: "G L WEber 1702", which settles the question of both the attribution and the time in which the work originated. According to the inscription, we are dealing with a very early work by Georg Leonhard Weber (c. 1672-1739), one of the leading sculptors of the late Baroque period in Lower Silesia, who was active in Świdnica. The outstanding Bratislava sculpture has so far been only mentioned and not discussed in detail in the literature. ${ }^{3}$ The present study is to expand the current modest state of research. It places the

\footnotetext{
${ }^{1}$ Some preliminary research needed to write the article was financed by the Narodowe Centrum Nauki under decision No. UMO-2012/07/B/HS2/01466.

${ }^{2}$ No. P 1958. For more on the sculpture, see: KELETI, Magda. Neskorá renesancia, manierizmus, barok v zbierkach SNG. Bratislava: Slovenská národná galéria, 1983, p. 218.

${ }^{3}$ KELETI, Neskorá renesancia..., p. 218; CHMELINOVÁ, Katarína. Beitrag zur Geschichte einer Künstlerfamilie im 18. Jahrhundert in Mitteleuropa. Der Bildhauer Joseph Leonhard Weber und Trnava/Tyrnau. In: Generationen. Interpretationen. Konfrontationen. BALÁŽOVÁ, Barbara (ed.), Bratislava: Ústav dejín umenia Slovenskej akademie vied, 2007, p. 154-155; KOLBIARZ, Artur. Michael Klahr Starszy, Paul Stralano and sculptures Baroque w Świdnicy. Nowe uwagi na temat edukacji artystycznej Klahra. In: Roczniki Sztuki Ślaskiej, 27, 2018, p. 147-148.
} 
work in a broader historical-cultural context and is an attempt to present the Bratislava sculpture against the background of Weber's entire oeuvre, his professional practice and activity on the art market.

Weber's professional activity is an excellent example of how a Silesian artist worked in circumstances of a confessional conflict between the Lutherans and the Catholics, which was an important factor influencing the art market. In that era of confessional disputes, art in the region was harnessed and used in the rivalry between the Protestants, who were a majority in the cities, and the Catholics, who were supported by the imperial authorities. ${ }^{4}$ Świdnica, where Weber lived and worked, occupied an important place among art centres influencing the evolution of late Baroque sculpture in Lower Silesia. ${ }^{5}$ In 1648, the Lutherans, who made up over $85 \%$ of the city's population, were forced to give all their churches to the Catholics, ${ }^{6}$ in exchange receiving the emperor's permission to build the Church of Peace. At the same time, the Catholic minority sought to strengthen its position, with the main role in the spread of Counter-Reformation being played by the Jesuits, who came to Świdnica as early as 1629. ${ }^{7}$ The activities of both denominations gradually led to an intensification of artistic endeavours in a process that was, however, by no means symmetrical. The confessional conflict in Świdnica was more intense than in other cities in Lower Silesia and its manifestations included the consistent use, not found elsewhere in the region, by both confessions of the services of artists only of the same faith. While in the late seventeenth and early eighteenth century there were few Lutheran sculptors in the city, there was a whole array of craftsmen working on the Catholic side. ${ }^{8}$

The growth of fine arts in Świdnica was inspired by the already mentioned Jesuits. The main artistic project of the order was a comprehensive Baroquisation of the city Church of St Stanislaus and St Wenceslas, taken over in 1662 from the Protestants. ${ }^{9}$ The works, which lasted until 1735, provided jobs for both Jesuit and secular sculptors, quickly turning Świdnica into an important local art centre. The first stage in the modernisation of the church, from 1666 to 1684, was carried out by various workshops, with the Jesuits having to also use artisans from outside Swidnica. ${ }^{10}$ The situation changed in 1692 when the convent set up its own workshop, supported when necessary by secular sculptors. At this stage of the Baroquisation, the dominant role was played by Johann Riedl (1654-1736), who was in charge of the whole project. The artist

\footnotetext{
${ }^{4}$ KALINOWSKI, Konstanty. Rzeźba barokowa na Ślasku. Warszawa: Państwowe Wydawnictwo Naukowe, 1986, p. 19-21, 39-41, 115-117; KOZIEL, Andrzej. Barokowy splendor klasztorów i pałaców. In: NIEDZIELENKO, Andrzej, VLNAS, Vít (eds.). Ślask. Perta w Koronie Czeskiej. Tray okeresy swietności w relacjach artystycznych Ślaska i Czech. Praha: Národní galeríe v Praze, 2006, p. 298; KOZIEL, Andrzej. Wstęp. In: KOZIEL, Andrzej (ed.) Malarstwo barokowe na Ślasku. Wrocław: Via Nova, 2017, p. 7-12.

${ }^{5}$ KALINOWSKI, Rzeźba barokowa..., p. 175; SACHS, Reiner, OSOSKO, Urszula. Czy rzeczywiście Konrad Rediger? In: Rocznik Muzeum Papiernictwa, 5, 2011, p. 11.

${ }^{6}$ HANULANKA, Danuta. Świdnica. Wrocław-Warszawa-Kraków-Gdańsk: Zakład Narodowy im. Ossolińskich, 1973, p. 28; SACHS, OSOSKO, Czy rzeczywiście Konrad..., p. 10.

${ }^{7}$ HOFFMANN, Herman. Die Jesuiten in Schweidnitz, Schweidnitz: Bergland - Verlag, 1930, p. 9; HANULANKA,

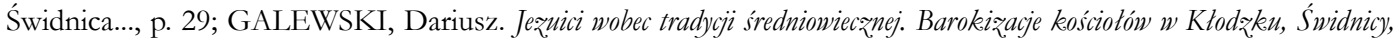
Jeleniej Górze i Żaganiu. Kraków: Universitas, 2012, p. 219.

${ }^{8}$ SACHS, Reiner, Sztuka Śląska od XVI do XVIII wieku. Uwagi Krytyczne. In: BARANOWSKI, Andrzej Józef (ed.) Sztuka pogranicay Rzeczypospolitej w okresie nowosytnym od XVI do XVIII wieku. Warszawa: Arx Regia, 1998, p. 80-81; SACHS, OSOSKO. Czy rzeczywiście Konrad..., p. 11-17.

${ }^{9}$ For more, see: GALEWSKI, Jezuici wobec tradycji..., p. 219-225, which also includes older literature on the subject.

${ }^{10}$ KOLBIARZ, Artur. Early Baroque Sculpture in Lower Silesia and Johann Georg Bendl. In: Umèní, 64(1), 2016, p. 51.
} 
obtained a basic education as a carpenter and sculptor in the 1670s in Bruntál and Kutná Hora, where he worked with the local masters (Christoph Dihl, Georg Riedl and Kaspar Eigler). He completed his education in Prague and then during a two-year stay in Lyon and Paris, where he got to know the latest trends in French art. After returning to Bohemia in 1682, he joined the Society of Jesus and ten years later was made a statuarius and arcularius in the Świdnica convent, becoming the head of the local fabrica Ecclesiae. ${ }^{11}$ His long career and fashionable models transplanted from abroad shaped the style of sculptures created in Świdnica's Catholic circles around 1700. When embarking on an enterprise that was beyond the capabilities of the Jesuit workshop, Riedl was forced to use the help of external artists, acting in such cases as an inventor responsible for the design and supervision of the works. In the early eighteenth century, the man who became Riedl's main collaborator was Georg Leonhard Weber, who worked on the decoration of the organ case, and on a series of monumental pillar figures. ${ }^{12}$ Weber, who came from Franconia, was just beginning his professional career. He is recorded in the sources in Świdnica for the first time on 14 November 1698, when he married Maria Magdalena Theresia Schuch. ${ }^{13}$ The following year he was made citizen of the city ${ }^{14}$ and lived there until his death at the age of 67 and a half, on 30 October 1739, in Nowe Miasteczko on the northern outskirts of the region. ${ }^{15}$

Despite the fact that the significance of both sculptors to the development of Baroque sculpture in Silesia has been often stressed in the literature, neither Riedel ${ }^{16}$ nor Weber ${ }^{17}$ has had - despite several announcements - modern monographs devoted to them that would correct

\footnotetext{
${ }^{11}$ GALEWSKI, Jezuici wobec tradycji..., p. 121-122; MIGASIEWICZ, Paweł. Inspiracje francuskie w rzeźbie figuralnej Johanna Riedla. Zarys problemu. In: GALEWSKI, Dariusz, JEZIERSKA, Anna (eds.) Silesia Jesuitica. Kultura i squtuka zakonu jezuitów na Ślasku i w brabstwie kłodzkim 1580-1776. Wrocław 2012, p. 217-225.

${ }^{12}$ OSTOWSKA, Danuta. Jerzy Leonard Weber. Rzeźbiarz śląski epoki baroku. In: Roczniki Sztuki Ślaskiej, II, 1963, p. 95; KALINOWSKI, Rzeźba barokowa..., p. 180.

${ }^{13}$ PATZAK, Bernhard. Die schlesische Baumeister Felix Anton Hammerschmidt und sein Bau des Grüssauer Prälatenhauses zi Schweidnitz. In: Der Wanderer im Riesengebirge, 50(5), 1930, p. 72; OSTOWSKA, Jerzy Leonard Weber..., p. 90 .

${ }^{14}$ BRAUN, Edmund Wilhelm. Studien zur schlesischen Barockplastik. Die künstlerische Entwicklung des Schweidnitzer Bildhauers Georg Leonhard Weber bis 1725. In: Kunst- und Denkmalpflege in Schlesien, vol. 2. Breslau-Lissa: Flemmings Verlag, 1939, p. 124.

${ }^{15}$ Archiwum Archidiecezjalne we Wrocławiu, Begräbnis-Buch Neustädtel, no. 246a, p. 12 verso. See also: SACHS, Sztuka Śląska..., p. 80.

${ }^{16}$ Worthy of note among the most important publications devoted to the artist are: HOFFMANN, Die Jesuiten..., p. 151-152, 314, 325; RYNEŠ, Vaclav, Umělci a umělečtí řemeslníci, jesuiští koadjutoři v barokní době. In: Umění, 6, 1958, p. 402-410; OSTOWSKA, Danuta. Rz̨éba ślaska 1650-1770. Wrocław: Muzeum Śląskie, 1969, p. 14-15, 42-45; KALINOWSKI, Rzeźba barokowa..., p. 176-179; GUMIŃSKI, Samuel. Jan Riedel i francuskie wątki w snycerce śląskiej przełomu XVII/XVIII wieku. In: WRABEC, Jan. (ed.) Michał Klahr Starszy i jego środowisko kulturowe. Wrocław: Uniwersytet Wrocławski. Centrum Badań Śląskoznawczych i Bohemistycznych, 1995, p. 133-141; MIGASIEWICZ, Paweł. Życiorys własny Johanna Riedla. Źródło historyczne do badań nad praktyką zawodową i kondycją społeczną rzeźbiarzy w dobie nowożytnej. In: Rocznikei Sztuki Ślaskiej, 21, 2012, p. 59-72; MIGASIEWICZ, Inspiracje francuskie..., passim; GALEWSKI, Jezuici wobec tradycji..., p. 121-122, 147, 153-155, 162-164, 168-169, 219-225.

${ }^{17}$ Worthy of note among the most important publications devoted to the artist are: BRAUN, Studien zur schlesischen..., p. 118-133; OSTOWSKA, Jerzy Leonard Weber..., passim; OSTOWSKA, Rzeźba śląska..., p. 15, 47-49; KALINOWSKI, Rzeźba barokowa..., p. 179-184; SACHS, Sztuka Śląska..., p. 80-81; GALEWSKI, Jezuici wobec tradycji..., p. 127, 169, 172, 220.
} 
the existing state of research, full of missing and contradictory information as it is. ${ }^{18}$ Although studies conducted in recent years into the art centre in Świdnica have produced a number of articles, these articles deal mainly with minor sculptors, selected questions or individual works. ${ }^{19}$ What is missing is an insightful analysis of the oeuvres of leading artists as well as a comprehensive study of the functioning of artists in Świdnica. This is an important issue, because in Weber's day there were nearly twenty sculptors active in the city. ${ }^{20}$ The style of some of these artists was similar to that of works by the author of the Bratislava figure (for example, Tobias Franz Stallmayer, Johann Karl Schönheim or Carl Sebastian Plag). In addition, early sculptures by Weber himself were clearly influenced by Riedl's works. All these circumstances make it difficult to formulate unequivocal conclusions, especially with regard to the attribution of unconfirmed works. Nevertheless, the Bratislava sculpture may be analysed in the context of Weber's oeuvre and of sculpture in Świdnica in general with the proviso that the final conclusions should wait for the forthcoming publications.

The Saviour figure from the SNG collection (Fig. 1) is, as of today, the only recognised work by Weber made in wood and bearing a signature. We have no information about the circumstances in which the Bratislava sculpture originated; however, the quality of the craftsmanship and the signature carved in a visible spot on the plinth suggest that the sculpture was made as a showpiece. Perhaps in this case - unlike in the case of ordinary commissions - the sculpture was made by the master himself, with a minimum contribution of the workshop. The small size of the figure, the level of detail on the whole surface and the lack of any traces of fixing suggest that it may have been displayed in public only temporarily, for example during Easter. It may also have been made not as an element of church furniture but as an item for a private collection. In such a case it would be one of the few surviving Silesian Baroque sculptures made with such an intention.

Signing the sculpture demonstrates the strategy used by the young artist just entering the art market and trying to attract potential customers. An "advertising" function was also performed by two of his stone works from the same period: a sculpture of Jove from Bolesławiec (1701)

\footnotetext{
${ }_{18}$ A monograph on Riedl was announced in 2012 by Paweł Migasiewicz. See: MIGASIEWICZ, Inspiracje francuskie..., p. 217. Ewa Grochowska's new findings concerning Weber, announced twenty years ago, are also awaiting publication. See: SACHS, Sztuka Śląska..., p. 81.

${ }^{19}$ SACHS, Rainer. SOKÓ£, Teresa, Cieplicka kolumna św. Floriana i jej twórcy. In: Rocznik Jeleniogórski, 32, 2000, p. 59-63; SACHS, Rainer. SOKÓE, Teresa. Życie i twórczość rzeźbiarza Tobiasa Franza Stallmayera (1673-1747). In: CZECHOWICZ, Bogusław (ed.) Dziedzictwo artystyczne Świdnicy. Wrocław-Świdnica: Polsko-Niemiecki Ośrodek Badań nad Dziedzictwem Kulturowym Śląska Stowarzyszenia Historyków Sztuki, 2003. p. 148-158; SACHS, Rainer, SOKÓL, Teresa. Johannes Schwibs - świdnicki Karinger. In: CZECHOWICZ, Bogusław (ed.) Dziedzictwo artystyczne Świdnicy. Wrocław-Świdnica: Polsko-Niemiecki Ośrodek Badań nad Dziedzictwem Kulturowym Śląska Stowarzyszenia Historyków Sztuki, 2003. p. 159-161; SACHS, Rainer. SOKÓE, Teresa. Świdnicki rzeźbiarz epoki późnego baroku - Johann Michael Monse. In: CZECHOWICZ, Bogusław (ed.) Dz̧iedzictwo artystyczne Świdnicy. Wrocław -Świdnica: Polsko-Niemiecki Ośrodek Badań nad Dziedzictwem Kulturowym Śląska Stowarzyszenia Historyków Sztuki, 2003, p. 163-166; GROCHOWSKA, Ewa. Pomnik maryjny w Dusznikach-Zdroju. Część 1. Zarys dziejów i problem ikonografii. In: Rocznik Muzeum Papiernictwa, 10, 2016, p. 81-96; MIGASIEWICZ, Inspiracje francuskie..., passim; MIGASIEWICZ, Życiorys własny..., passim.

${ }^{20}$ SACHS. OSOSKO, Czy rzeczywiście Konrad..., p. 11-15.
} 


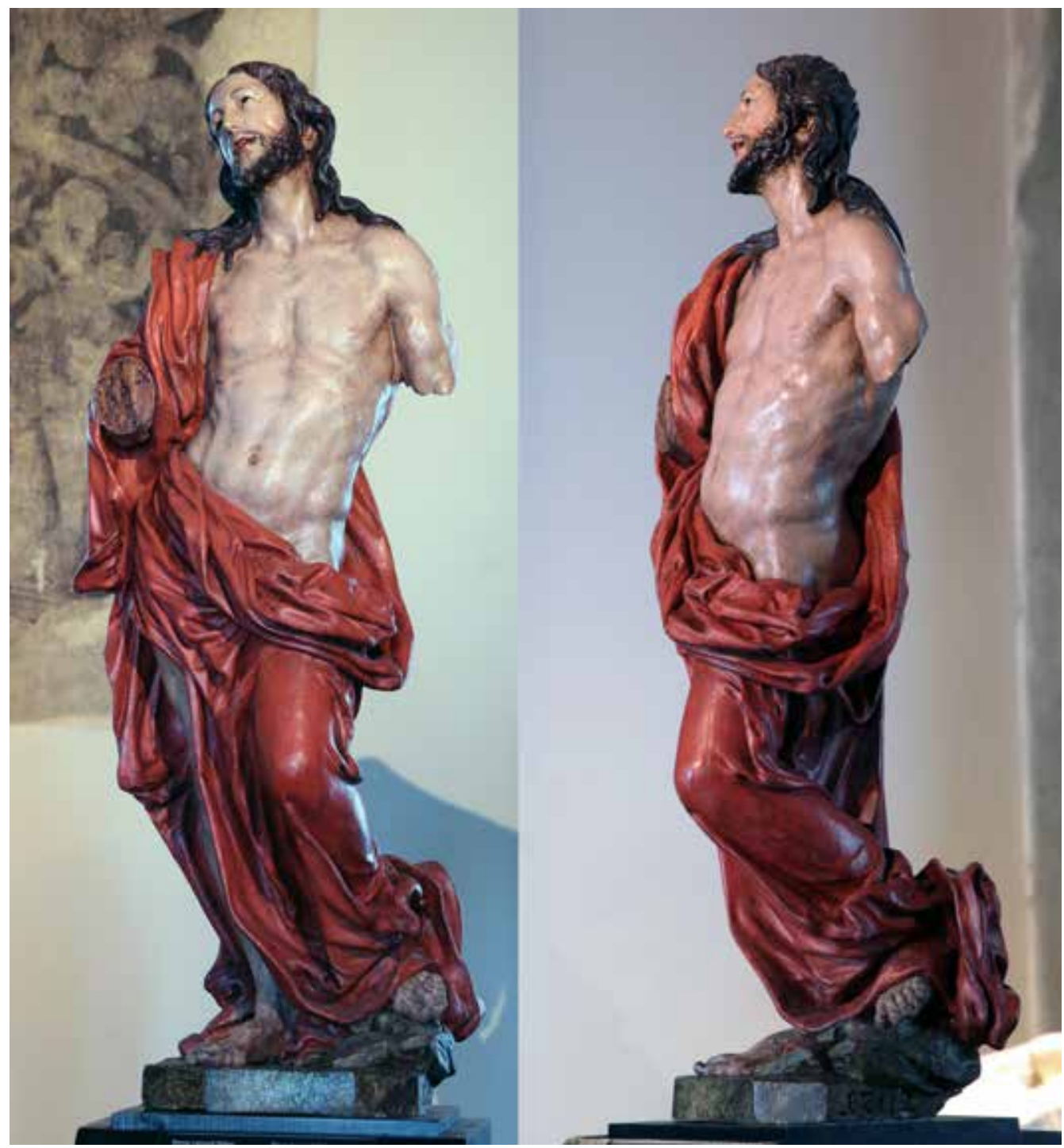

Figure 1: Georg Leonhard Weber, The Sculpture of Christ the Saviour, 1702, Slovak National Gallery, Bratislava.

and a Marian column in Kochanów (1702). ${ }^{21}$ Both had inscriptions with information about the authorship carved in visible spots. In order to make it easier for potential customers to find the author, the inscriptions give Weber's first names and last name in full and, in the case of the Bolesławiec sculpture, also name the city in which he worked. ${ }^{22}$ Interestingly, the artist stopped signing his works after 1702. Perhaps later, when commissions kept coming in - and Weber was one of the most prolific Baroque sculptors in Silesia - there was no longer a need for such obvious self-promotion. From the very beginning Weber sought to make his mark on an art

\footnotetext{
${ }^{21}$ For more, see: CZECHOWICZ, Bogusław. DOBRZYNIECKI, Arkadiusz. Kolumna maryjna w Kochanowie nieznane dzieło Jerzego Leonarda Webera. In: DZIURLA, Henryk (ed.) Krzeszón uśniecony łaska. Wrocław: Uniwersytet Wrocławski, 1997, p. 331-336.

${ }^{22}$ See BRAUN, Studien zur schlesischen..., p. 124.
} 
market much larger than Świdnica. This is evidenced by a number of works from that period and made for customers from outside the city. ${ }^{23}$ Such mercantile tactics appear to have worked: the professional success Weber enjoyed definitely eclipsed the career of any other secular sculptor active in Świdnica in the eighteenth century.

The formal origins of the Bratislava sculpture of the Saviour reveals a compilation-driven approach, typical of the period, to the creation of the artist's own inventions based on various sources. As fate would have it, Czech and Polish museums still have works from Weber's atelier, which - together with works to be found in churches - illustrate the development of his artistic concept. The work is among the few Silesian examples for which we can indicate a design study. It is in the form of a terracotta model kept in the Silesian Museum in Opava, part of a group of five bozzetti which found their way into the Opava museum from the collection of Engelbert Kaps (1888-1975). ${ }^{24}$ Until recently the whole group - given the highlighted dynamism of the figures as well as use of thick, longitudinal drapery - was mistakenly attributed Thomas Weisfeldt (Weissfeldt), ${ }^{25}$ a Norwegian master regarded as one of the leading Wrocław sculptors from the early eighteenth century, associated with the expressive manner in Silesian sculpture.

${ }^{23}$ In 1702 , or possibly in 1717 , the artist made four stone figures for the fountains in the abbot's gardens of the Cistercian Monastery in Henryków. The earlier date has been proposed by Danuta Ostowska, see: OSTOWSKA, Jerzy Leonard Weber..., p. 94-95. The later origin has been advocated by Krzysztof Eysymontt, see: EYSYMONTT, Krzysztof. Klasztorne ogrody i park nowej rezydencji w Henrykowie. In: Kwartalnik Architektury i Urbanistyki, 17(30), 1972, p. 212-223. Most authors accept Ostrowska's dating.

In 1701 a John of Nepomuk column was erected in Wierzbna, which belonged to the Krzeszów Cistercians. An identical monument with a figure of Our Lady on top, also erected in Wierzbna, may come from the same period. A comparative analysis suggests that both works should be linked to Weber. This attribution is also supported by the patronage of the Krzeszów Cistercians, for whom the artist made the Kochanów column one year later. For the same patrons the Świdnica artist also made the stone figures of the Madonna with Child and St John of Nepomuk placed in Chełmsk Ślaski. As the inscription is now blurred, it is impossible to date the work precisely, but given the formal analogies to the above-mentioned works, the Marian figure may have been an early work by Weber.

Another piece to be found in the provinces and which can be tentatively described, on the basis of comparisons, as an early work by the artist, is a wall statue of St John of Nepomuk from the church in Budzów, funded, according to the inscription, in 1705 by, among others, Caspar Ferdinand Steiner, a trade commissioner from Świdnica and a juror in Stoszowice. The thick and extraordinarily ornamental lines of the drapery and the detail of the saint's head bring to mind Weber's figures, made at the same time, for the organ case in the Church of St Stanislaus and St Wenceslas in Świdnica.

It was also probably at the beginning of Weber's career that he made the first works for patrons from outside Silesia: figural decorations for the organ case and a wall Crucifixion group in the former Bernardine Church in Kłodzko, decorated in 1704-1711 (dating after KÖGLER, Joseph. Die Chroniken der Grafschaft Glatz, vol. 2, [new ed.] POHL, Dieter. Modautal: Dr Dieter Pohl Verlag, 1993, p. 127). The sculptures of King David and St Cecilia repeat the composition of figures from the Świdnica organ case. The less ornate form of the cloak in the Kłodzko sculpture of David is modelled on the pillar representation of St Lawrence from Świdnica. See: KOLBIARZ, Michael Klahr Starszy..., p. 150, 156.

${ }^{24}$ No. G 60.110. I would like to thank Mr Martin Janák, curator of the old art collection at the Silesian Museum in Opava for providing me with access to the sculptures and information about their origins.

${ }^{25}$ BRAUN, Edmund Wilhelm. Studien zur schlesischen Barockplastik. Bozzetti vom Breslauer Bildhauer Thomas Weisfeldt und aus seiner Werkstatt. In: Kunst- und Denkmalpflege in Schlesien. vol. 2, Breslau-Lissa: Flemmings Verlag, 1939, p. 134-139; NOWAK, Romuald. Schlesische Barockbozzetti. In: KALINOWSKI, Konstanty (ed.) Studien zur Werkstattpraxis der Barockskulptur im 17. und 18. Jabrbundert, Poznań: Uniwersytet im. Adama Mickiewicza, 1992, p. 116-119; HLADÍK, Tomáš. Sochařská dílna obdobi baroka ve strédní Evropè. Od návrbu k provedení. Praha: Národní Galeríe v Praze, 2016, p. 51-54. 

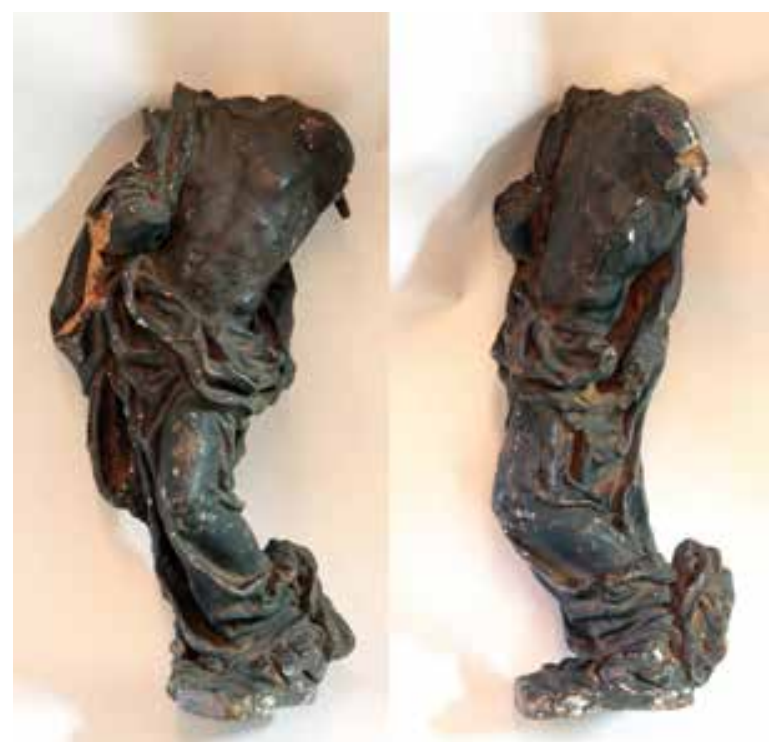

Figure 2: Georg Leonhard Weber (attrib.), The Bozzetto for a Sculpture of Christ the Saviour, c. 1700 , Silesian Museum, Opava.

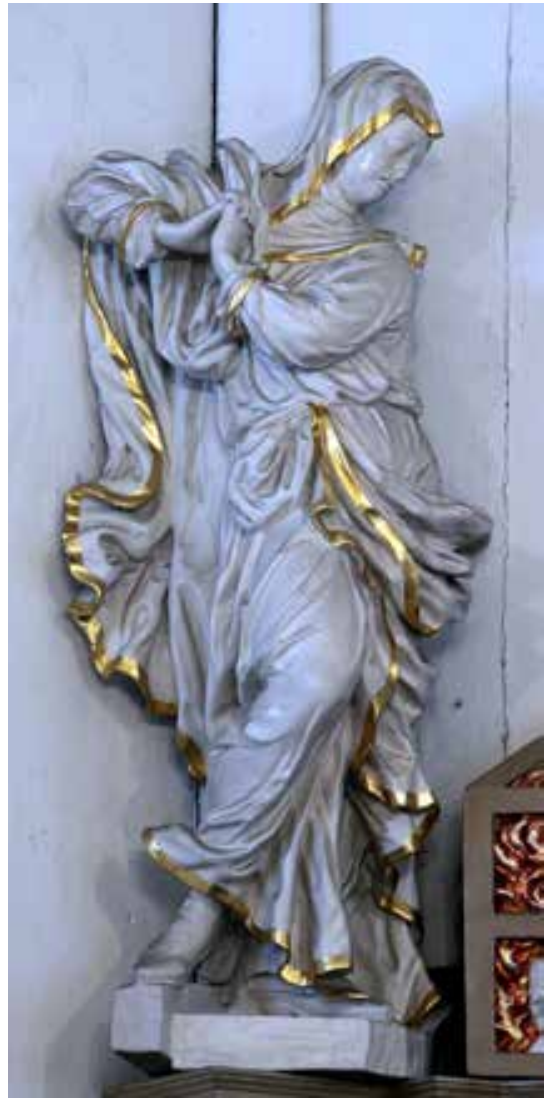

Figure 3: Georg Leonhard Weber (attrib.), The Sculpture of Our Lady of Sorrows, before 1739, Church of St Barbara, Żelazny Most.

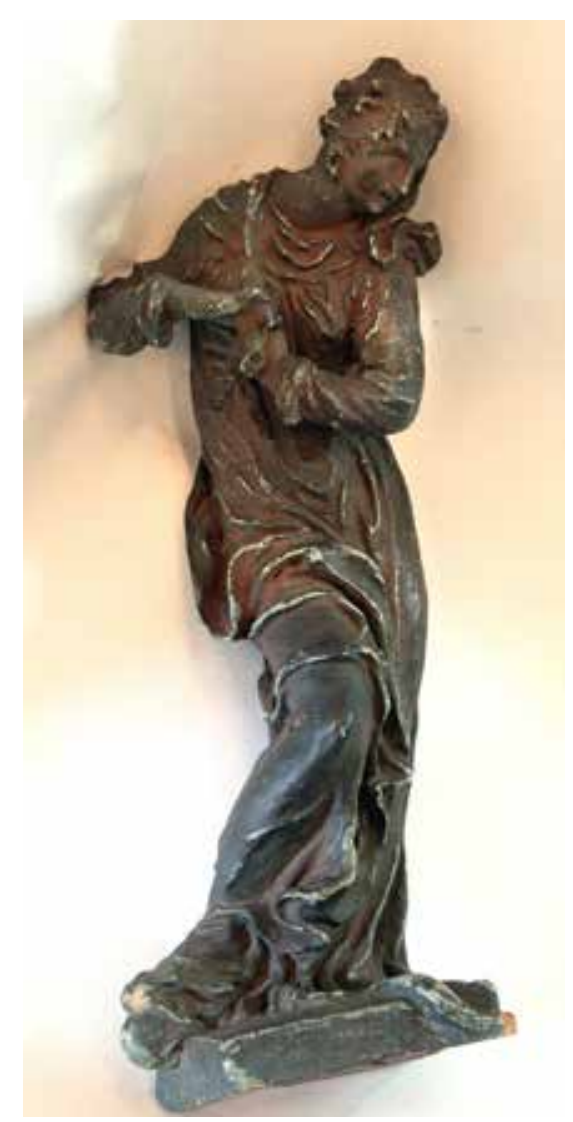

Figure 4: Georg Leonhard Weber (attrib.), The Bozzetto for a Marian Sculpture, c. 1700, Silesian Museum, Opava. 
There are many arguments for attributing the whole set of the Opava sketches to Weber. ${ }^{26}$ First of all, the Bratislava sculpture of the Saviour by the Świdnica artist follows the same pattern as the Opava bozzetto with an analogous theme (Fig. 2). The analogies concern not only the composition and the proportions. They can also be found in the level of detail: in the arrangement of softly modelled longitudinal draperies which emphasise the curved line of the figure, as well as in the idealised and athletic muscles with a characteristic high rib arc, trapezoidal greater pectoral muscles and indentation between the straight abdominal muscles, from the navel to the sternum. Without a doubt the Opava sketch must have been a preliminary study for the Bratislava figure, for the shape of the robes and the body is identical in all views, including the detailed side and back parts.

When it comes to the other Opava bozzetti, clear links to the figure of Our Lady of Sorrows from the main altar in the church in Żelazny Most (Fig. 3) ${ }^{27}$ can to found in the sketch to the Marian figure (Fig. 4). ${ }^{28}$ Yet, unlike the case of the Saviour figure, it was not a direct design, but a starting point for a new concept. Both Marian sculptures have an exceptionally dynamic position of the body and exaggerated gesticulation. However, the robe in the wooden figure differs from the Opava sketch mainly in its richer form of the cloak. All Opava bozzetti have robes typical of woks from Weber's workshop. The rich folds of the robes do not dematerialise the body. The dominant element is the fine lines of narrow and longitudinal draperies with slightly irregular edges combined with smooth body-fitting fragments of the garment.

The sketches also contain detailed solutions characteristic of Weber's works. For example, the terracotta figure of St Scholastica has a habit sleeve decorated with telescopic draperies, while its edge has a characteristic outline resembling a falling drop of a thick fluid. ${ }^{29}$ Another original solution found in the Opava sculpture is a pattern made of delicate folds resembling a mesh of veins and adding variety to a broad surface of the robe covering a protruding thigh. All these solutions can be found in the figure of St Anthony decorating the top of the altar of the Virgin and Child with Saint Anne, erected in 1717 in the former Cistercian Church in Cieplice, ${ }^{30}$ as well as the sculptures of Franciscan friars from the top of altar of St John of

\footnotetext{
${ }^{26}$ The Opava models were linked for the first time to Weber in: KOLBIARZ, Michael Klahr Starszy..., p. 148-149. The attribution of the Opava models to Weisfeldt stemmed largely from insufficient knowledge and incorrect characterisation of Weber's oeuvre (see: ibid., p. 145-147).

${ }^{27}$ The figures from the church in Żelazny Most were linked for the first time to Weber's workshop by Danuta Ostowska. OSTOWSKA, Rzeźba śląska..., p. 48-49.

${ }^{28}$ Slezské zemské muzeum v Opave. No. G 60.114.

${ }^{29}$ Slezské zemské muzeum v Opave. No. G 60.112.

${ }^{30}$ So far the altar has remained unattributed. A comparative analysis suggests that the decoration of the reredos and the structurally similar altar of Our Lady of Succour should be linked to Weber's workshop. The Świdnica artist or one of his close associates should also be linked to the decorations of the altar of the Fourteen Holy Helpers (c. 1716) and figural groups representing St Andrew and St Jude the Apostle flanking the main altar (c. 1716) in the Cieplice church. The attribution is confirmed by the circumstances in which the works originated. All were funded by the benefactor of the Cieplice church, Count Johann Anton Schaffgotsch, who used Weber's services several times. As early as 1712, the Świdnica sculptor carved for him a stone figure of St John of Nepomuk, located in Cieplice (See: OSTOWSKA, Jerzy Leonard Weber..., p. 98). In 1720 he made the sculpture of St Florian at the corner of Świdnica City Hall. Schaffgotsch was also one of the donors funding the Chapel of Blessed Ceslaus (1725-1730), a prestigious commission in which Weber was designated the chief artist to create sculpted decorations (See: OSTOWSKA, Jerzy Leonard Weber..., p. 104; KALINOWSKI, Rzeźba barokowa..., p. 183).
} 


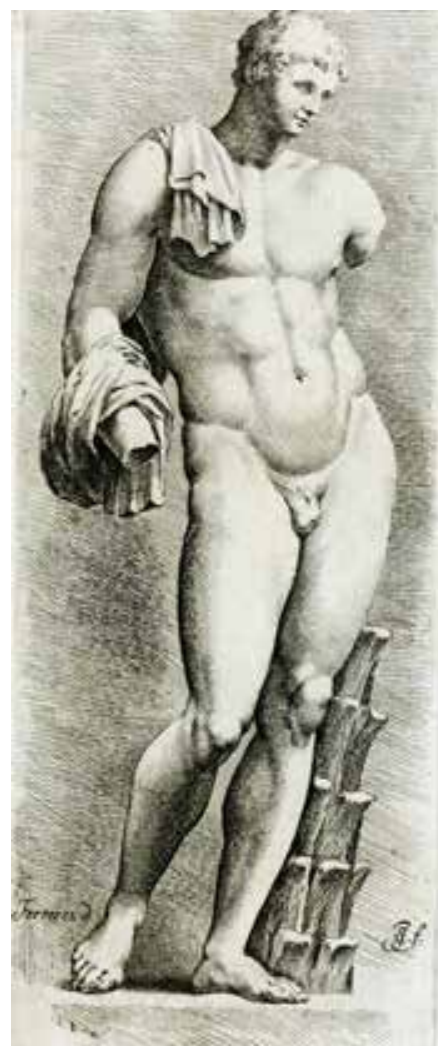

Figure 5: Jan de Bisschop, The Engraving of Hermes (Belvedere Antinous) from "Signorum Veterum Icones", 1670, Amsterdam.

Nepomuk in the Church of the Assumption in Bolesławiec (c. 1723-1725). ${ }^{31}$

A comparison between the Bratislava figure of the Saviour with the works from Opava makes it possible to follow several aspects of the practice applied in Weber's workshop. Bozzetti were a commonly used intermediary stage in sculpture making, during which a master would give a material form to his concepts before creating the final version of the work in the intended material. ${ }^{32}$ That the Opava sculptures are not preliminary ideas, the so-called pensieri, but designs ready to be transferred to a bigger scale is evidenced by the hollowing out at the back of all figures (with the exception of the Saviour, from the beginning designed as a sculpture to be viewed from all sides). This kind of form of the back part of the sculpture, of no significance in terracotta, is desirable for technological reasons in the case of large wooden sculptures. At the same time, it designates the material in which the figures were to be ultimately carved.

Weber was one of the few sculptors in Silesia in the Baroque period to use terracotta bozzetti. The ability to mould terracotta - more common in Southern and Western than in Central Europe - may have been a result of his collaboration with Riedl, who, after his apprenticeship in France, may have preferred this particular material. The question of whether Weber also made wooden models, alongside terracotta ones, must remain unanswered at this point. It is possible, as is evidenced by examples of sculptors active in the Kingdom of Bohemia at the time and making sketches in various materials as needed. This was the practice, for example, in the workshops of Matthias Bernhard Braun $^{33}$ and Michael Klahr the Elder. ${ }^{34}$

When designing the Bratislava sculpture of the Risen Christ, Weber drew inspiration from art available locally and referred to supraregional and timeless canons. The arrangement of the figure, with the leg thrust forward, slightly exaggerated counter-pose, and head leaning to one side - all making the figure shaped like an elongated letter " $\mathrm{S}$ " - was quite popular in early modern art. This approach has roots in ancient art and sculptures, developing the ideas of Polykleitos' famous Doryphoros. The compositional style was also known in Świdnica, as is evidenced by the angelic figures decorating the main altar erected by Johann Riedl's workshop in 1692-1694. The extraordinary elegance of the composition, grace and lightness characteris-

\footnotetext{
31 The altar was decorated in 1726, while in 1723-1725 Weber erected the main altar in the Bolesławiec church, a work for which he received around 600 thalers. See: WERNICKE, Ewald. Chronik der Stadt Bunzlau von den ältesten Seiten bis zur Gegenwart. Bunzlau: Verlag von G. Kretschmer, 1884, p. 427-428. A comparative analysis suggests that the decoration of the altar of St John of Nepomuk should be linked to Weber or to another sculptor from his circle. ${ }^{32}$ For more on the process of making Baroque sculptures, see: KALINOWSKI, Konstanty. Warsztat barokowego rzeźbiarza. In: Artium Quaestiones, 7, 1995, p. 113-122; HLADÍK, Sochařská dílna..., p. 25-119.

${ }^{33}$ See: HLADÍK, Sochařská dílna..., p. 79-85.

${ }^{34}$ See: GERNAT, Jacek. Projekty, bozzetti, modelletti, modelli i wzorniki - uwagi na temat praktyki warsztatowej rzeźbiarskiej rodziny Klahrów w XVIII-XIX w. In: Rocz̧niki Sz̨tuki Ślaskiej, 27, 2018, p. 22-29.
} 


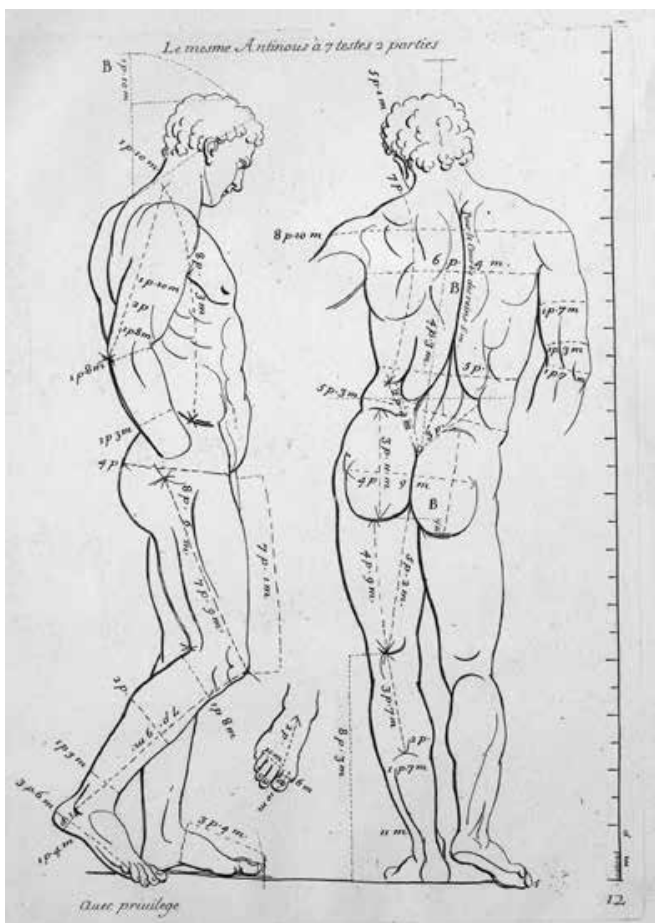

Figure 6: Gérard Audran, The Engraving of Hermes (Belvedere Antinous) from 'Les proportions du corps humain, mesurées sur les plus belles figures de l'Antiquité", 1683, Paris.

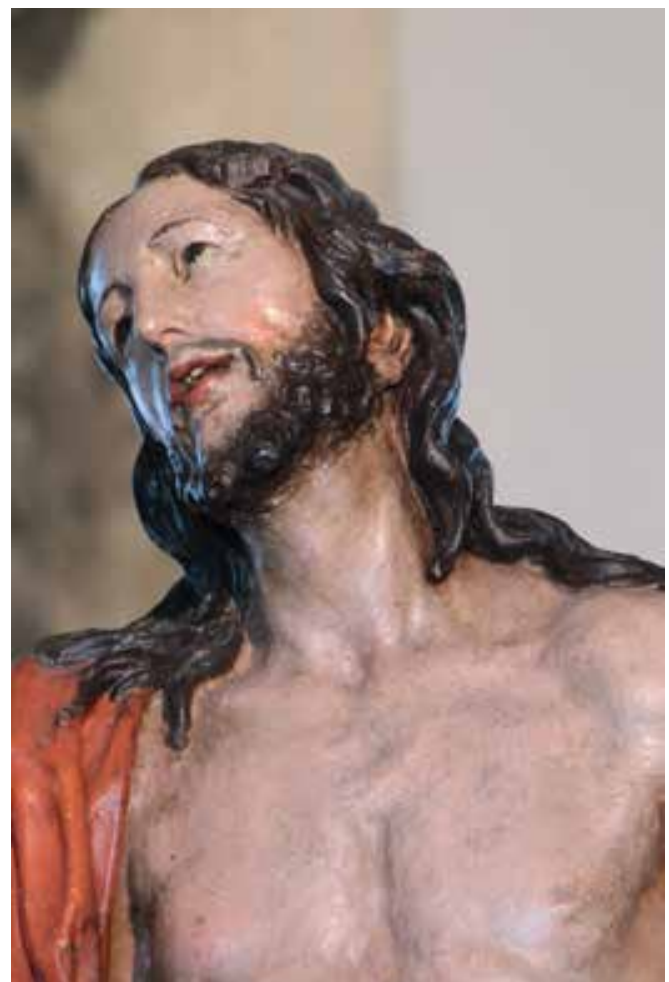

Figure 7: Georg Leonhard Weber, Part of the Sculpture of Christ the Saviour, 1702, Slovak National Gallery, Bratislava.

ing the Bratislava Saviour seem, however, to go beyond standard references to the Baroque art of the region. They bring to mind the achievements of Greek masters from the late classical period, primarily Praxiteles and his followers. The possible inspirations Weber may have used probably included images of the figure of Hermes (known in the past as the Belvedere Antinous) from the Museo Pio-Clementino. The sculpture was purchased in 1543 by Pope Paul III, and the Vatican Belvedere quickly became highly admired in artistic circles. In the early modern period it was popularised by prints, including Jan de Bisschop's collection, Signorum Veterum Icones, published in Amsterdam in 1670 (Fig. 5). We do not know whether Weber had access to this particular work or whether he used other iconographic sources, but his Saviour is a quite faithful mirror reflection of the posture reproduced in the print, with the exception of the slightly differently inclined head. Similarities can also be seen in the outline of pectoral and abdominal muscles, high rib arc and rhomboidal indentation in the middle of the sternum - a mode present in numerous sculptures from the Świdnica artist's workshop.

The skill in presenting a muscular body in the Bratislava figure is also higher than the average level of Silesian sculptors of the day. The highlighted parts of the body are carved with nearly academic correctness, revealing the artist's considerable familiarity with the anatomy of the human body. In this respect Weber must have owed a lot to Riedl, who on numerous occasions demonstrated his skill in correctly representing a nude body, idealised in accordance with the requirements of French sculpture of the mid-seventeenth century. Perhaps Weber - who did not have an academic education and never went to France - honed his skills by studying anat- 


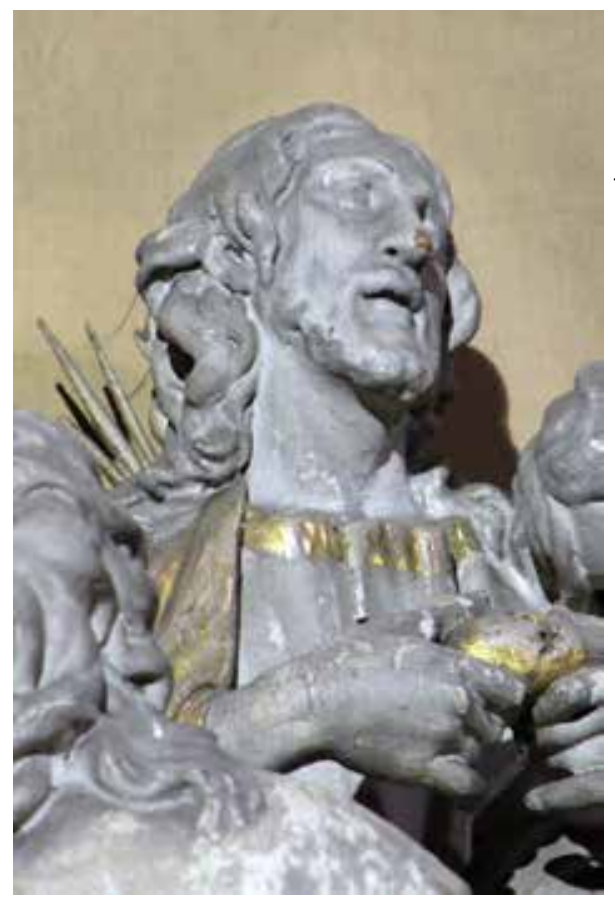

Figure 8: Johann Riedel, Georg Leonhard Weber, Part of the Sculpture of Christ from the Altar of St Ignatius Loyola, 1699 or 1703 , Church of St Stanislaus and St Wenceslaus, Świdnica.

resulted most likely from the collaboration between the two artists on the furnishings of the order's church in the 1700s. Nor can we rule out the possibility that Weber - before embarking on a career on his own - worked as Riedl's helper in the monastery's fabrica Ecclesiae.

Weber was an artist of great invention and, despite his huge oeuvre, his workshop rarely copied earlier compositions. The exceptions include the design of the Bratislava sculpture, which was subsequently repeated several times. The first example is the free-standing sculpture from the Church of St Stanislaus in Roztoka (Fig. 9) ${ }^{36}$ However, the Roztoka sculpture has additional elements strengthening the message of the Saviour's triumph over Death and Sin. Christ is not standing directly on the plinth, but is trampling on a skeleton and a dragon

\footnotetext{
${ }^{35}$ Drawings from this textbook were owned by Michael Klahr the Elder, a sculptor working for the Society of Jesus in Kłodzko in the 1710s and 1720s. This is important, because the Kłodzko Jesuits maintained close links with their Świdnica brothers, and Klahr was well familiar with the oeuvres of Riedl and Weber. We do not know, however, how Klahr came across the textbook. One of the possibilities is Świdnica, where the French art-oriented Riedl may have had the publication purchased. Cf.: KOLBIARZ, Michael Klahr Starszy..., p. 156.

${ }^{36}$ Originally Lutheran, the church was taken over by the Catholics in 1945, when it received its current dedication. In order to adapt it to the requirements of Roman Catholic worship, most furnishings from the nearby Catholic church were transferred there. Weber's workshop produced the main altar (without the figure of the nun), with only the figure of St Peter still remaining in the Roztoka church. The Crucifixion group was transferred to the Diocesan Curia in Świdnica. The church still houses the Saviour carved in the Świdnica workshop and crowning the baptismal font, and the Pieta.
} 


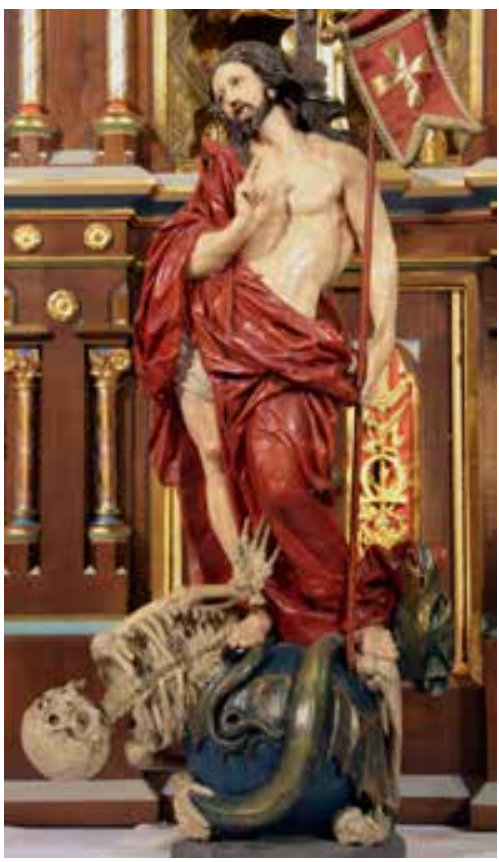

Figure 9: Georg Leonhard Weber (attrib.), The Sculpture of Christ the Saviour, before 1739, Church of St Stanislaus, Roztoka.

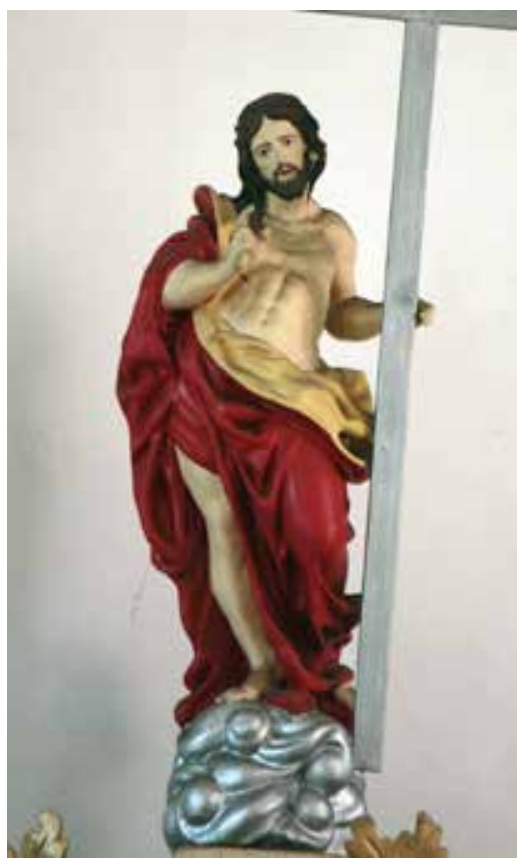

Figure 10: Georg Leonhard Weber (attrib.), The Sculpture of Christ the Saviour, before 1739, Church of St Joseph, Lagiewniki.

entwined around the globe. The figure of the Saviour itself is virtually a copy of the earlier composition, with the exception of slightly more stocky proportions and higher placement of the diagonal folds of the robe over the hips. Differences can also be found in its less developed muscles, modified lines of the drapery and a different concept of the head. Despite these divergences, the Roztoka figure was undoubtedly made in Weber's workshop. However, it was not made as a showpiece standing out by virtue of its quality in comparison with the entire oeuvre; the workmanship was on a decent level. The question of attribution is settled by formal analogies between the differently carved head and confirmed works by Weber. The round face with gently arching eyebrows, straight nose and almond-shaped eyebrows copies the modes used in the personification of Prudentia placed as a caryatid in the altar mensa of the Blessed Ceslaus Chapel in the Church of St Adalbert in Wrocław (c. 1725-1730). ${ }^{37}$ In addition, the beard arranged in a decorative knot made up by two locks can be found in the figure of St John of Nepomuk from the main altar of the parish church in Rudna near Nowa Sól (1739). ${ }^{38}$

Among the motifs added to the sculpture from the church in Roztoka, the most interesting is the image of Death. With a high level of carved detail and a theatrical pose corresponding to the figure of the triumphant Christ, it is presented as an in transi type, with remnants of cartilages and internal organs, and - despite visible simplifications - confirms the author's general familiarity with the anatomy of the human body. Similarities to Weber's mature works make it possible to date the sculpture from the Roztoka church to the 1720 s or possibly the 1730 s.

\footnotetext{
${ }^{37}$ Attribution and dating after KALINOWSKI, Rzeźba barokowa..., p. 182-183.

${ }^{38}$ An altar hitherto without attribution. The question of authorship is settled by archive documents. See: Archiwum Diecezjalne w Zielonej Górze, Rechnungs-Buch Rauden, no. PNS-kat 24, no pagination, entry under: "Den 15te Sept: [1739] dem Schweinitzer Bildhauer H: Leonarth Weebir, vor ein Neues Altar 115 Rthl”.
} 


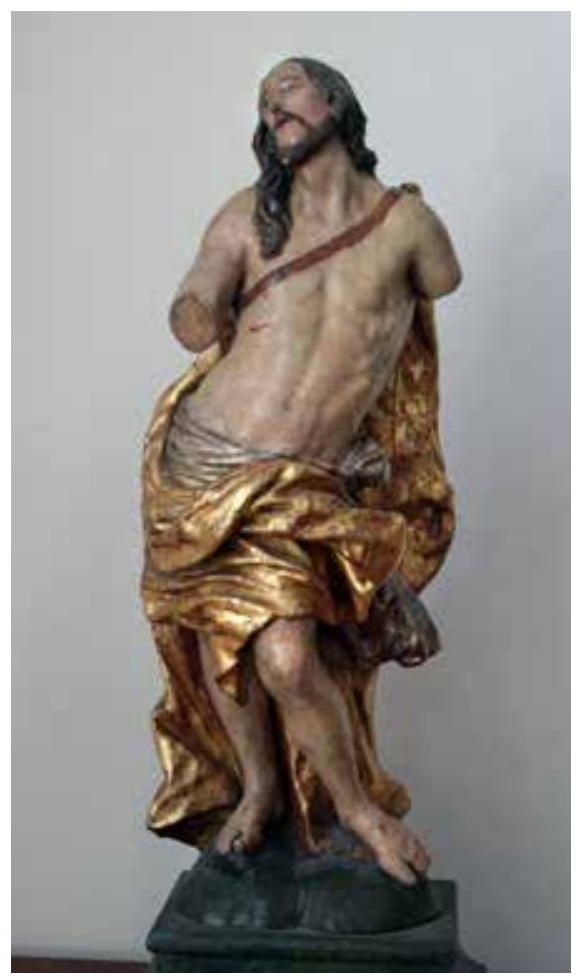

Figure 11: Georg Leonhard Weber (attrib.), The Sculpture of Christ the Saviour, 1720 s or 1730 s,

Museum Ziemi Lubuskiej, Zielona Góra.

It was probably commissioned from someone among the von Hochbergs, who owned the village and were patrons of the church. ${ }^{39}$

Weber's workshop repeated the same composition - in a slightly modified variant - in the sculpture crowning the pulpit from the parish church in Lagiewniki (Fig. 10). Unfortunately, the secondary imposed paintings profoundly blur the sculptural modelling - especially in the head parts - making it difficult to make a definitive comparative analysis of the work. The slight simplification of the mantle modelling may mean a more substantial contribution by workshop helpers. On the other hand, some parts of the robe - especially the coattail cloak falling from the shoulder - have a drapery duct even closer to the bozzetto from Opava than seen in a sculpture from Bratislava. However, we cannot exclude for sure the possibility the sculpture was carved outside Weber's atelier (by an artist from Weber's circle), though this option is less likely. ${ }^{40}$

Among the recognized Silesian Baroque sculptures there are at least three more figures that originated in Weber's studio - eventually made by artists from his circle - and constituting variants of the concept in question. What they have in common is the position of the figure, copied from the Bratislava sculpture, but they differ completely in the form of the robes. The first figure (Fig. 11) comes from the collection of the Muzeum Ziemi Lubuskiej in Zielona Góra and was transferred there in the 1970s from an undefined church in the Głogów District. ${ }^{41}$ In this case, too, we are dealing with a work made in the workshop. However, this time the simplified form of the details distinctly lowers the quality of the sculpture. The shallowly carved torso no longer brings to mind the statue of the ancient hero. Just as sketchy as the torso are the facial features. The average elaboration of the body is partly recompensed by an arrangement

\footnotetext{
${ }^{39}$ Weber had the opportunity to work for Hans Heinrich III von Hochberg on the alteration of the Roztoka Palace in 1720-1725. Evidence includes the coat of arms reset in the portal of the garden facade in the nineteenth century. Details in the armour, helmets and draperies, as well as the faces of the knights flanking the cartouche leave no doubt as the authorship of Weber and his workshop. Analogies can be found in the figures of St Florian from the workshop of the Świdnica master: in Świdnica's Market Square (1720), from the top of the chapel above the side entrance to the pilgrimage church in Grodowiec (c. 1720), from the altar of St Anne in the former Cistercian Church in Cieplice and from the main altar of the church in Szymocin (1720s or 1730s).

${ }^{40}$ The history of the work remains unknown. Currently, the sculpture is a part of the pulpit erected in the nineteenth century. However, we do not know whether it originally decorated the previous pulpit or whether it went to the church in Lagiewniki secondarily.

${ }^{41}$ No. MZG-SD-I-84. I would like to thank the deputy director of the Zielona Góra museum, Dr Longin Dzieżyc, for providing me with access to the Sculpture and information about its origins. For the basic information about the sculpture, see: TOCZEWSKI, Andrzej, DZIEŻYC, Longin (eds.) W krequ ślaskiej sztuki sakralnej. Zabytki Ślaska Lubuskiego XIV-XVIII w. ze zbiorów Muzeum Ziemi Lubuskiej w Zielonej Górze, Zielona Góra 2002, p. 54. The similarity between the Zielona Góra and Bratislava sculptures were suggested for the first time in CHMELINOVÁ, Beitrag zur Geschichte..., p. 162.
} 


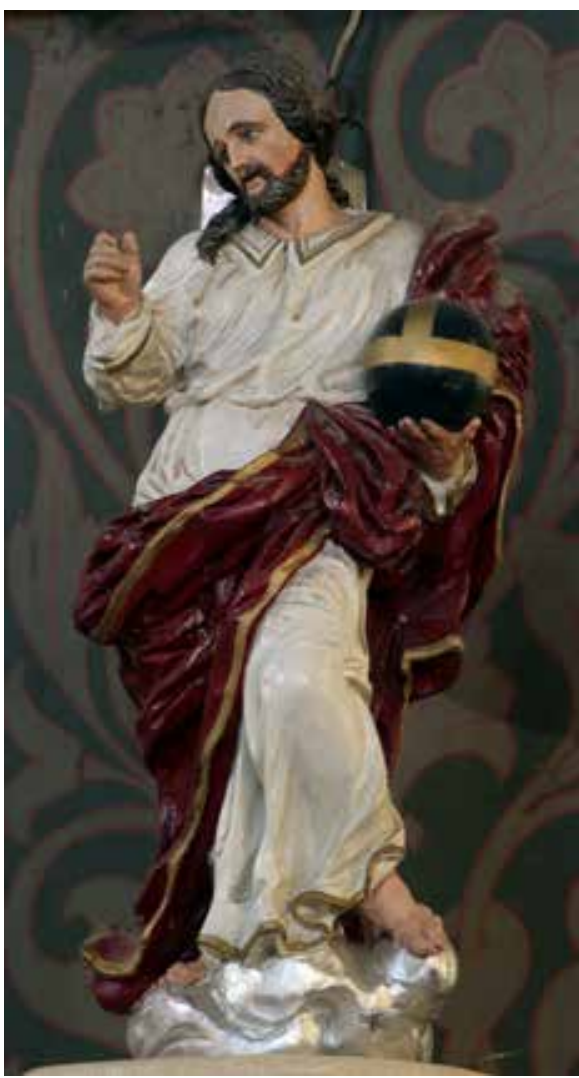

Figure 12: Georg Leonhard Weber or Sculptor from his Circle (attrib.), The Sculpture of Christ the Saviour, before 1739, The Church of St Stanislaus, Roztoka. of the robe, elegantly wrapped around the hips. Despite its lower quality, the formal modes found in the sculpture make it possible to link it to Weber's workshop. The elongated face with an excessively pointed chin resembles the design known from the stone figure of St Joseph $(1723)^{42}$ placed in front of the church in Bolesławiec, and the statue of St Jude the Apostle standing next to the main altar in the former Cistercian Church in Cieplice (c. 1716). The motif of a single lock of hair flowing over the shoulder onto the breast is a copy of an idea from the Christ figure adorning the top of the main altar in Bolesławiec (1723-1725).

The second sculpture - which differs the most from the others in terms of its form - is to be found in the parish church in Roztoka, crowning the baptismal font (Fig. 12). In the case of this figure, the dominant role is playing by the finely draped robe tightly covering the body. The arrangement of the cloak partly resembles the composition seen in the above-mentioned figures, while the folds of the underrobe emphasise the curve of the Saviour's torso. The same version of the Christ the Saviour sculpture was also used in the figure adorning the main altar in the parish church in Lutomia Dolna (Fig. 13). At the present stage of research, authorship of both these last sculptures is unclear; they show as few differences in the execution of detail as might be made by two different helpers in Weber's studio or by two unidentified artists from his circle.

The analysed works demonstrate the ease with which Weber was able to compose variants of the garments on one position of the body. In this respect, he was by no means unique in Silesia. Similar practices were followed by a leading Wrocław sculptor, Thomas Weisfeldt. ${ }^{43}$ At the design stage, both artists may have used a mannequin over which they draped the robes in order to achieve their purpose.

In the context of the evolution of artistic concepts associated with the Bratislava figure of the Saviour, just as interesting are two works made outside Weber's atelier. The figure of Christ (Fig. 14), not mentioned in the literature, from the Church of St Wenceslas and St Stanislaus in Świdnica is similar in size to the Bratislava statue. It, too, is carved on all sides and intended for occasional display. It has a similar arrangement of the body as well as similar - although of lower quality - level of detail in the muscles, with a different concept for the arrangement of the robe. The form of drapery, as well as facial details, suggests that the Świdnica figure was probably made by Riedl or his workshop - or, alternatively, by an unknown artist from his

\footnotetext{
${ }^{42}$ The sculpture was commissioned by Sebastian Josef Wolfgeil, Mayor of Bolesławiec. KALINOWSKI, Rzeźba barokowa..., p. 181-182.

${ }^{43}$ KOLBIARZ, Artur. Udział Thomasa Weisfeldta (Weissfeldta) w barokizacji wrocławskiej katedry. In: KACZMAREK, Romuald, GALEWSKI, Dariusz (eds.) Katedra wroctawska na przestrzeni tysiaclecia. Studia z historii architektury $i$ sætuki. Wrocław 2016, p. 255-257.
} 


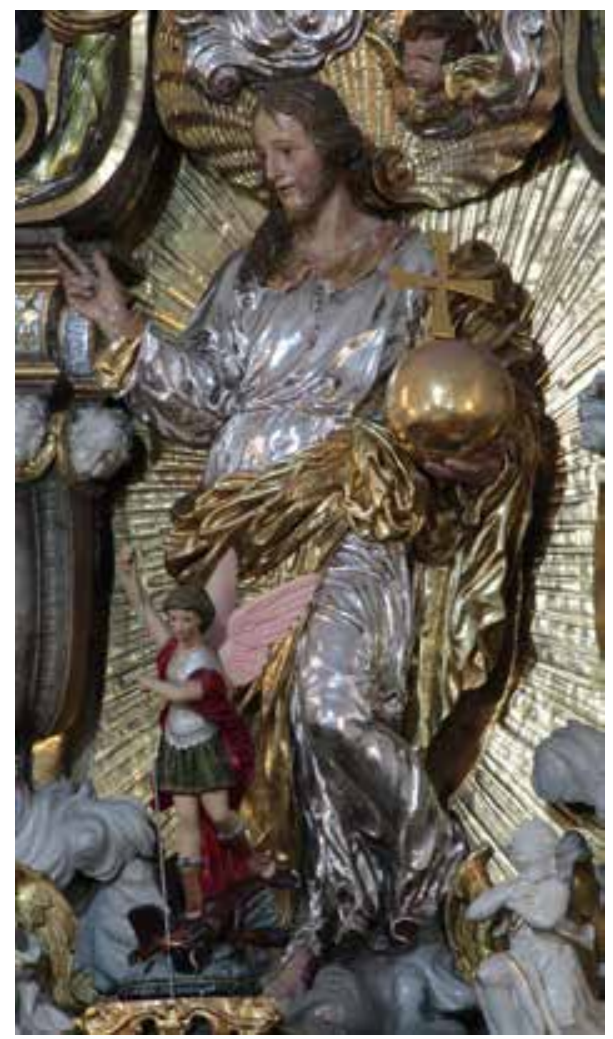

Figure 13: Georg Leonhard Weber or Sculptor from his Circle (attrib.), The Sculpture of Christ the Saviour, 1700s or 1710s, Church of Transfiguration of Jesus, Lutomia Dolna.

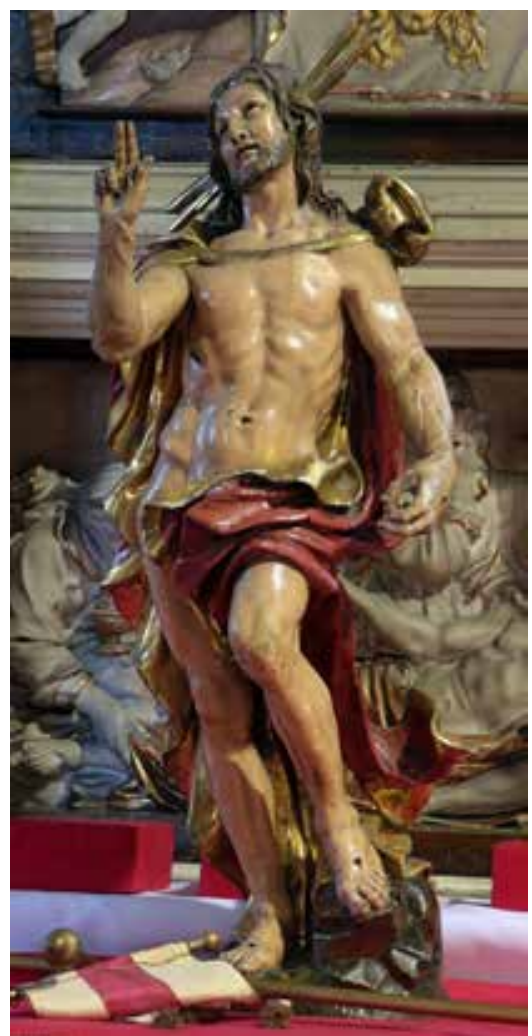

Figure 14: Johann Riedel or Sculptor from his Circle (attrib.), The Sculpture of Christ the Saviour, c. 1700, Church of St. Stanislaus and St. Wenceslaus, Świdnica.

circle. The relatively massive folds of the cloak and flowing cascades at the bottom bring to mind the garments of the figures adorning the sounding board of the Świdnica pulpit (1698), while the facial details are closest to the figure of the Saviour from the Gethsemane group by the wall, works traditionally linked to the Jesuit artist. ${ }^{44}$ A lack of information about the dating of the work in question makes it impossible to determine whether it was made before or after the Bratislava figure. However, the visible shortcomings (less than perfect proportions, rigid movement and mediocre reproduction of the uncovered parts of the body) make it an unlikely model for the sculpture carved by Weber. Undoubtedly, both draw on the prints depicting the Roman Hermes, but Weber proved more skilful in using and transforming the ancient example.

The last of the figures - of Triumphant Christ, closing the whole evolutionary series - is part of the furnishings of the Church of St Bartholomew in Radzikowice near Nysa. ${ }^{45}$ Like the works discussed earlier, it is a free-standing sculpture. Its composition is a copy of the Bratislava concept, both in the positioning of the figure and arrangements of the robes. However, the proportions are stockier and the detail completely different - more generalised and devoid of Weber's typical realism. Stylistically, the figure is a late Baroque work and should be

\footnotetext{
${ }^{44}$ KALINOWSKI, Rzeźba barokowa..., p. 176; GALEWSKI, Jezuici wobec tradycji..., p. 220.

${ }^{45}$ So far the sculpture has only been mentioned in the literature. See: CHRZANOWSKI, Tadeusz. KORNECKI, Marian. Katalog zabytkón w Polsce, vol. 7, Województwo opolskie, no. 9 Powiat nyski, Warszawa: Polska Akademia Nauk, 1963, p. 170.
} 
approximately dated to the second third of the eighteenth century. Its author must have had direct contact with at least one of Weber's statues of the Saviour (from Świdnica, Radzikowice or Lagiewniki), but his professional training, taking into account the most current trends in art, enabled him to transform the original. The name of the author of the Radzikowice sculpture is unknown, but he was undoubtedly an artist familiar with the art centre in Świdnica. What remains an open question is whether he was one of Weber's three sons, who were also sculptors.

In conclusion it is worth raising one more issue: the manner in which the Saviour sculpture found its way into today's Slovakia, although the current state of research makes it impossible to provide an unequivocal answer. Georg Leonhard Weber probably did not venture that far when he was active as an artist. The literature does contain information that the sculptor apparently travelled to neighbouring Brno in $1700-1704,{ }^{46}$ but it has proved impossible to confirm this. On the other hand, there is evidence of his presence in Świdnica in that period. However, it is impossible to exclude a shorter stay in the Moravian capital which may have been associated with the transport or making of the statue in question. Another hypothetical possibility is the agency of one of Weber's sons - Joseph Leonhard, who after leaving Silesia worked in Brno, and in 1749 settled in Trnava, where he functioned until his death in $1771 .^{47}$ Theoretically, the sculpture, a gift of his father, may have travelled with the artist to Moravia or Upper Hungary.

The Saviour figure from the SNG collection in Bratislava is an exceptional piece in Weber's oeuvre. It belongs to a limited group of extraordinary works by the Świdnica master, for example: decoration of the Blessed Ceslaus Chapel, sculptures from pillars of Świdnica's Jesuit church, figures in the main altar of a church in Śmiałowice or bust gallery from the former palace of the Krzeszów abbots in Świdnica. Signed and made with virtuosic precision in a classicising convention, it is the highlight of an early stage of Weber's career, testifying to his broad artistic horizons as well. Also, it constitutes a link between various works made in Świdnica's master workshop over nearly four decades.

The present study demonstrates the advantages of an interdisciplinary analysis of museum collections. Using research tools of art history, history and archival studies, it provides a context for the sculpture in question, highlighting its significance to the cultural heritage of Central Europe. It makes it possible to introduce corrections into the existing museum catalogues or make them more precise. Another important aspect is the international nature of the research into gallery collections, involving institutions from Slovakia, the Czech Republic and Poland. Such an approach makes it possible to find links and expand the state of research in the various countries, opening up new possibilities for both museologists and art historians. Finally, the results may become an inspiration for exhibition projects. After all, the developmental sequence

\footnotetext{
${ }^{46}$ NOWAK, Romuald. Rzę̧́ba ślaska XVI-XVIII wieku. Katalog q biorów. Wrocław: Muzeum Narodowe we Wrocławiu, 1994, p. 177.

${ }^{47}$ For more on Joseph Leonhard, see: CHMELINOVÁ, Beitrag zur Geschichte..., passim. Given the discrepancy in the year of birth, stemming from contradictory records, the author doubts that Joseph Leonhard of Trnava was the son of Weber of Świdnica with the same names (ibid., p. 155). Yet the Weber active in Trnava undoubtedly came from Świdnica, as is confirmed by the entry relating to his acquisition of citizen's rights. Owing to a lack of information about two sculptors named Weber active in Świdnica at the turn of the eighteenth century and having sons with the same names, what seems more likely is a mistakenly recorded age of the artist on his death leading to a discrepancy with regard to his birth date.
} 
in the composition of the Bratislava statue of the Saviour indicated above could be a highlight of any exhibition tackling questions concerning the creation of a work of art.

Translation: Anna Kijak

\section{References}

Archive sources

Archiwum Archidiecezjalne we Wrocławiu, Begräbnis-Buch Neustädtel, No. 246a.

Archiwum Diecezjalne w Zielonej Górze, Rechnungs-Buch Rauden, no. PNS-kat 24.

\section{Literature}

BRAUN, Edmund Wilhelm (1939). Studien zur schlesischen Barockplastik. Die künstlerische Entwicklung des Schweidnitzer Bildhauers Georg Leonhard Weber bis 1725. In: Kunst- und Denkmalpflege in Schlesien. vol. 2, Breslau-Lissa: Flemmings Verlag, p. 118-133.

BRAUN, Edmund Wilhelm (1939). Studien zur schlesischen Barockplastik. Bozzetti vom Breslauer Bildhauer Thomas Weisfeldt und aus seiner Werkstatt. In: Kunst- und Denkmalpflege in Schlesien. vol. 2, Breslau-Lissa: Flemmings Verlag, p. 134-139.

CHMELINOVÁ, Katarína (2007). Beitrag zur Geschichte einer Künstlerfamilie im 18. Jahrhundert in Mitteleuropa. Der Bildhauer Joseph Leonhard Weber und Trnava/Tyrnau. In: BALÁŽOVÁ, Barbara. (ed.) Generationen. Interpretationen. Konfrontationen. Bratislava: Ústav dejín umenia Slovenskej akademie vied, p. 151-163.

CZECHOWICZ, Bogusław (1997). DOBRZYNIECKI, Arkadiusz. Kolumna maryjna w Kochanowie - nieznane dzieło Jerzego Leonarda Webera. In: DZIURLA, Henryk. (ed.) Krzeszów uswięcony taska. Wrocław: Uniwersytet Wrocławski, p. 331-336.

EYSYMONTT, Krzysztof (1972). Klasztorne ogrody i park nowej rezydencji w Henrykowie. In: Kwartalnike Architektury i Urbanistyki, 17(3), p. 211-228.

GALEWSKI. Dariusz (2012). Jezuici wobec tradycji średniowiecznej. Barokizacje kościołów w Kłodzk.u, Świdnicy, Jeleniej Górze i Żaganiu. Kraków: Universitas.

GERNAT, Jacek (2018). Projekty, bozzetti, modelletti, modelli i wzorniki - uwagi na temat praktyki warsztatowej rzeźbiarskiej rodziny Klahrów w XVIII-XIX w. In: Rocz̨niki Sz̧tuki Ślaskiej, 27, p. 19-62.

GROCHOWSKA, Ewa (2016). Pomnik maryjny w Dusznikach-Zdroju. Część 1. Zarys dziejów i problem ikonografii. In: Rocznik Muzeum Papiernictwa, 10, p. 81-96.

GUMIŃSKI, Samuel (1995). Jan Riedel i francuskie wątki w snycerce śląskiej przełomu XVII/ XVIII wieku. In: WRABEC, Jan. (ed.) Michat Klahr Starsyy i jego środowisko kulturowe. Wrocław: Uniwersytet Wrocławski. Centrum Badań Śląskoznawczych i Bohemistycznych, p. 133-141.

HANULANKA, Danuta (1973). Świdnica. Wrocław-Warszawa-Kraków-Gdańsk: Zakład Narodowy in. Ossolińskich.

HLADÍK, Tomáš. Sochařská dína obdobi baroka ve stredni Evropè. Od návrbu ke provedení. Praha: Národní Galeríe v Praze, 2016.

HOFFMANN, Herman (1930). Die Jesuiten in Schweidnitz, Schweidnitz: Bergland - Verlag.

KELETI, Magda (1983). Neskorá renesancia, manierizmus, barok v zbierkach SNG. Bratislava: Slovenská národná galéria. 
KALINOWSKI, Konstanty (1986). Rz̨eźba barokowa na Ślasku. Warszawa: Państwowe Wydawnictwo Naukowe.

KALINOWSKI, Konstanty (1995). Warsztat barokowego rzeźbiarza. In: Artium Quaestiones, 7 , p. 103-140.

KOLBIARZ, Artur (2018). Michael Klahr Starszy, Paul Stralano i rzeźba barokowa w Świdnicy. Nowe uwagi na temat edukacji artystycznej Klahra. In: Roczniki Sztuki Ślaskiej, 27, p. 121-158.

KOLBIARZ, Artur (2016). Early Baroque Sculpture in Lower Silesia and Johann Georg Bendl. In: Umèní, 64 (1), p. 44-56.

KOLBIARZ, Artur (2016). Udział Thomasa Weisfeldta (Weissfeldta) w barokizacji wrocławskiej katedry. In: KACZMAREK, Romuald, GALEWSKI, Dariusz (eds.) Katedra wrockawska na przestrzeni tysiaclecia. Studia z historii architektury i sztuki. Wrocław, p. 249-265.

KOZIE屯, Andrzej (2006). Barokowy splendor klasztorów i pałaców. In: NIEDZIELENKO, Andrzej, VLNAS, Vít (eds.) Ślask. Perła w Koronie Czeskiej. Trzy okresy śmietności w relacjach artystyczuych Ślaska i Czech. Praha: Národní galeríe v Praze, p. 297-313.

KOZIEŁ, Andrzej (2017). Wstęp. In: KOZIEŁ, Andrzej (ed.) Malarstwo barokowe na Ślasku. Wrocław: Via Nova, p. 7-20.

KÖGLER, Joseph (1993). Die Chroniken der Grafschaft Glatz, vol. 2, (new ed.) POHL, Dieter. Modautal: Dr Dieter Pohl Verlag.

MIGASIEWICZ, Paweł (2012). Inspiracje francuskie w rzeźbie figuralnej Johanna Riedla. Zarys problemu. In: GALEWSKI, Dariusz, JEZIERSKA, Anna (eds.) Silesia Jesuitica. Kultura i sztuka zakonu jezuitón na Ślasku i w hrabstwie kłodzkim 1580-1776. Wrocław, p. 217-225.

MIGASIEWICZ, Paweł (2012). Życiorys własny Johanna Riedla. Źródło historyczne do badań nad praktyką zawodową i kondycją społeczną rzeźbiarzy w dobie nowożytnej. In: Roczniki Szztuki Ślaskiej, 21, p. 59-72.

NOWAK, Romuald (1992). Schlesische Barockbozzetti. In: KALINOWSKI, Konstanty (ed.) Studien zur Werkstattpraxis der Barockskulptur im 17. und 18. Jahrbundert, Poznań: Uniwersytet im. Adama Mickiewicza, p. 115-137.

NOWAK, Romuald (1994). Ržé́ba ślaska XVI-XVIII wieku. Katalog zbiorów. Wrocław: Muzeum Narodowe we Wrocławiu.

OSTOWSKA, Danuta (1963). Jerzy Leonard Weber. Rzeźbiarz śląski epoki baroku. In: Roczniki Sztuki Ślaskiej, 2, p. 92-116.

OSTOWSKA, Danuta (1969). Ržé́ba ślaska 1650-1770. Wrocław: Muzeum Śląskie.

PATZAK, Bernhard (1930). Die schlesische Baumeister Felix Anton Hammerschmidt und sein Bau des Grüssauer Prälatenhauses zi Schweidnitz. In: Der Wanderer im Riesengebirge, 50(5), p. 70-72.

RYNEŠ, Vaclav (1958). Umělci a umělečtí řemeslníci, jesuiští koadjutoři v barokní době. In: Umèní, 6, p. 402-410.

SACHS, Reiner (1998). Sztuka Śląska od XVI do XVIII wieku. Uwagi Krytyczne. In: BARANOWSKI, Andrzej Józef (ed.) Sztuka pograniczy Rzeczypospolitej w okresie nowożytnym od XVI do XVIII wieku. Warszawa: Arx Regia, p. 80-81.

SACHS, Reiner, OSOSKO, Urszula (2011). Czy rzeczywiście Konrad Rediger? In: Rocznik Muzeum Papiernictwa, 5, p. 9-20.

SACHS, Rainer, SOKÓL, Teresa (2000). Cieplicka kolumna św. Floriana i jej twórcy. In: Rocそnik Jeleniogórski, 32, p. 59-63. 
SACHS, Rainer, SOKÓ£, Teresa (2003). Życie i twórczość rzeźbiarza Tobiasa Franza Stallmayera (1673-1747). In: CZECHOWICZ, Bogusław (ed.) Driedzictwo artystyczne Świdnicy. Wrocław-Świdnica: Polsko-Niemiecki Ośrodek Badań nad Dziedzictwem Kulturowym Śląska Stowarzyszenia Historyków Sztuki, p. 148-158.

SACHS, Rainer, SOKÓ£, Teresa. (2003). Johannes Schwibs - świdnicki Karinger. In: CZECHOWICZ, Bogusław (ed.) Dziedzictwo artystyczne Świdnicy. Wrocław-Świdnica: Polsko-Niemiecki Ośrodek Badań nad Dziedzictwem Kulturowym Śląska Stowarzyszenia Historyków Sztuki, p. 159-161.

SACHS, Rainer, SOKÓ£, Teresa (2003). Świdnicki rzeźbiarz epoki późnego baroku - Johann Michael Monse. In: CZECHOWICZ, Bogusław (ed.) Džiedzictwo artystyczne Świdnicy. Wrocław-Świdnica: Polsko-Niemiecki Ośrodek Badań nad Dziedzictwem Kulturowym Śląska Stowarzyszenia Historyków Sztuki, p. 163-166.

TOCZEWSKI, Andrzej, DZIEŻYC, Longin (eds.) (2002). W kregu ślaskiej sztuki sakralnej. Zabytki Ślaska Lubuskiego XIV-XVIII w. ze z̧biorów Muzeum Ziemi Lubuskiej w Zielonej Górže, Zielona Góra.

WERNICKE, Ewald (1884). Chronik der Stadt Bunzlau von den ältesten Seiten bis zur Gegenwart. Bunzlau: Verlag von G. Kretschmer. 